\title{
RUN Domain-Containing Protein 1
}

National Cancer Institute

\section{Source}

National Cancer Institute. RUN Domain-Containing Protein 1. NCI Thesaurus. Code C158536.

RUN domain-containing protein $1(613 \mathrm{aa}, \sim 68 \mathrm{kDa}$ ) is encoded by the human RUNDC1 gene. This protein is involved in the inhibition of cellular tumor antigen p53 activity. 